\title{
Increased Expression of Golli Myelin Basic Proteins Enhances Calcium Influx into Oligodendroglial Cells
}

\author{
Pablo M. Paez, Vilma Spreuer, Vance Handley, Ji-Ming Feng, Celia Campagnoni, and Anthony T. Campagnoni \\ Semel Institute for Neuroscience and Human Behavior, University of California at Los Angeles Geffen Medical School, Los Angeles, California 90095
}

The myelin basic protein (MBP) gene encodes two families of proteins: the classic MBP constituents of myelin and the golli-MBPs, the function of which is less well understood. Previous work suggests that golli proteins may play a role in $\mathrm{Ca}^{2+}$ homeostasis in oligodendrocytes (OLs) and in T-cells. Overexpression of golli in OL cell lines induces elaboration of sheets and processes. Live imaging of these cells revealed a rapid retraction of the processes and sheets after depolarization with high $\mathrm{K}^{+}$. This phenomenon was associated with a significant increase in $\left[\mathrm{Ca}^{2+}\right]_{\text {int }}$ without changes in cell viability. The results indicated that golli produced its effect through $\mathrm{Ca}^{2+}$ influx, rather than $\mathrm{Ca}^{2+}$ release from intracellular stores. Furthermore, a specific $\left[\mathrm{Ca}^{2+}\right]_{\text {int }}$ chelator (BAPTA) or $\mathrm{Cd}^{2+}$, a specific blocker of voltage-operated $\mathrm{Ca}^{2+}$ channels, abolished the ability of golli to promote process extension in a dose-dependent manner. Analysis of the golli protein identified a myristoylation site at the $\mathrm{C}$ terminus of the golli domain, which was essential for the action of golli on $\mathrm{Ca}^{2+}$ influx, suggesting that binding of golli to the plasma membrane is important for modulating $\mathrm{Ca}^{2+}$ homeostasis. High-resolution spatiotemporal analysis along $\mathrm{N} 19$ processes revealed higher-amplitude local $\mathrm{Ca}^{2+}$ influx in regions with elevated levels of golli. These findings suggest a key role for golli proteins in regulating voltage-gated $\mathrm{Ca}^{2+}$ channels in OLs during process remodeling. Our observations are consistent with the hypothesis that golli proteins, as a part of a protein complex, modulate $\mathrm{Ca}^{2+}$ influx at the plasma membrane and along $\mathrm{OL}$ processes.

Key words: golli proteins; oligodendrocyte; calcium influx; process extension; voltage-gated calcium channels; myelin proteins

\section{Introduction}

The myelin basic protein (MBP) gene encodes two families of proteins: the "classic" MBPs and the golli proteins (Campagnoni et al., 1993; Pribyl et al., 1993). In mouse, three golli products have been identified: BG21, J37, and TP8 (Campagnoni et al., 1993). Unlike the classic MBPs, golli proteins are expressed in myelin-forming cells as well as in neurons in the CNS and peripheral nervous system (Landry et al., 1996, 1997, 1998; Pribyl et al., 1996) and in macrophages and T-cells in the immune system (Feng et al., 2000). Golli proteins first appear in many neurons when they are extending processes for migration, establishment of connections and, in the case of oligodendrocytes (OLs), before myelination (Landry et al., 1996, 1997, 1998; Pribyl et al., 1996). In vitro transfection studies have shown that overexpression of golli proteins in OL cell lines can induce these cells to elaborate extensive processes and membrane sheets, adopting a morphology similar to mature OLs in culture (Reyes and Campagnoni, 2002).

OLs and their function are impaired by the selective ablation of golli proteins (Jacobs et al., 2005). The golli knock-out (KO)

\footnotetext{
Received May 24, 2007; revised Sept. 28, 2007; accepted 0ct. 1, 2007.

This work was supported by National Institutes of Health Grants NS23022 and NS33091 and in part by a postdoctoral fellowship from the National Multiple Sclerosis Society.

Correspondence should be addressed to Dr. Anthony T. Campagnoni, Semel Institute for Neuroscience and Human Behavior, University of California at Los Angeles Geffen Medical School, Neuroscience Research Building, 635 Charles Young Drive, Los Angeles, CA 90095-7332. E-mail: acampagnoni@mednet.ucla.edu. DOI:10.1523/JNEUROSCI.2381-07.2007

Copyright $\odot 2007$ Society for Neuroscience $\quad$ 0270-6474/07/2712690-10\$15.00/0
}

animals suffer from delayed and reduced myelination in selective regions of the brain, such as the visual cortex and forebrain. Impaired formation of myelin sheets in primary cultures of cortical OLs (Jacobs et al., 2005) indicated that at least part of this hypomyelination is caused by intrinsic problems with the OLs. Similar results were found in a new transgenic mouse called JOE (J37 golli overexpressor) in which the golli J37 isoform is overexpressed specifically in OLs under the control of a classic MBP promoter (Martin et al., 2007).

Jacobs et al. (2005) showed that $\mathrm{Ca}^{2+}$ homeostasis is altered in OLs from golli-deficient mice. Although resting $\mathrm{Ca}^{2+}$ levels did not differ between the KO and wild-type (WT) OLs, the magnitudes of the $\mathrm{Ca}^{2+}$ response to a variety of stimuli were significantly blunted. For example, $\mathrm{Ca}^{2+}$ transients induced by high $\mathrm{K}^{+}$, PMA, and caffeine were all significantly reduced in the golli KO OLs. Additionally, recent findings have clearly established that golli protein plays a critical role in regulating $\mathrm{Ca}^{2+}$ influx in T-cells (Feng et al., 2006). All these data suggest a role for golli on $\mathrm{Ca}^{2+}$ signaling regulation.

Several studies have addressed the importance of $\mathrm{Ca}^{2+}$ signaling in OL differentiation and myelination (Soliven, 2001) as well as in process extension and OL migration (Simpson and Armstrong, 1999; Yoo et al., 1999) and retraction of membrane sheets and cell death in mature mouse OLs (Benjamins and Nedelkoska, 1996).

The present study was undertaken to assess the role of golli in the process of OL process extension and retraction and to examine its relationship to the regulation of $\mathrm{Ca}^{2+}$ signaling. 


\section{Materials and Methods}

Construction of the green fluorescent protein clones. The construction of the full-length 337 and BG21 clones in pEGFP-N3 was described by Reyes and Campagnoni (2002). J37 deletions 1 and 2 were constructed by amplifying portions of 37 cDNA in pGEM-3Zf ${ }^{-}$using a common $3^{\prime}$ primer, TGAATTCTTGGTACCGCGTCTCGCCATGGGAGA, and the following 5'primers, CAATTAGCTAGCGAATTCAATGGTGTTTGGGGAGGCAGA (Del1) and CATTAGCTAGCGAATTCAATGGACAGGCCCTCAGAGTC (Del2). DNA insert amplification was performed in accordance with the manufacturer's recommendations (Invitrogen, Rockville, MD). The cycling conditions were as follows: (1) $5 \mathrm{~min}$ at $95^{\circ} \mathrm{C}$ for $1 \mathrm{cycle}$; and (2) $3 \mathrm{~min}$ at $95^{\circ} \mathrm{C}, 2 \mathrm{~min}$ at $68^{\circ} \mathrm{C}$, and $2 \mathrm{~min}$ at $72^{\circ} \mathrm{C}$ for 30 cycles. The product was digested with EcoRI-KpnI and inserted into pEGFP-N3 in frame with the green fluorescent protein (GFP).

The myristoylation mutations were made by site-directed mutagenesis (Clontech, Palo Alto, CA) using the J37 and BG21 enhanced GFP (EGFP) clones and the following oligonucleotide: 5'-GCTCAAGCTTCGAATTCATGGCCAACCACTCTGG-3'; the selection marker was a BglII to ScaI mutation. The same strategy was used to delete amino acids 25-40, a putative calmodulin-binding region (J37 NoCalm), with the primer $5^{\prime}$ GGAGAGATTCACCGAGGAGAGGACAGTGATGTGTTTGGG-3' and an AatII to EcoRV selection mutation on a pGEM3 clone. This clone was transferred to pEGFP-N3 using the same PCR primers as J37. The region between Del1 and Del2 (Del3) was removed from a pGEM3 clone with AatII to EcoRI selection and the following primer: 5'CGGCCTCAGAGGACAGTGAT/AGGCCCTCAGAGTCCG-3'. It was also inserted into pEGFP-N3 with the J37 primers.

Cell line preparation and transfection. The N19 conditionally immortalized cell line was grown in DMEM and Ham's F-12 (1:1 v/v) (Invitrogen, Carlsbad, CA), containing $100 \mu \mathrm{g} / \mathrm{ml}$ gentamycin and $100 \mu \mathrm{g} / \mathrm{ml}$ G418 sulfate (Omega Scientific, Tarzana, CA), supplemented with 4 $\mathrm{mg} / \mathrm{ml}$ dextrose anhydrous, $3.75 \mathrm{mg} / \mathrm{ml}$ HEPES buffer, $2.4 \mathrm{mg} / \mathrm{ml}$ sodium bicarbonate, and 10\% fetal bovine serum (FBS) (Omega Scientific, Tarzana, CA). Cultures were maintained at $34^{\circ} \mathrm{C}$ with $5 \% \mathrm{CO}_{2}$. Cells plated onto poly-D-lysine-coated $12 \mathrm{~mm}$ glass coverslips were transfected using the Lipofectamine 2000 (Invitrogen). Briefly, $1 \mu \mathrm{g}$ of plasmid DNA was used to transfect $4.5 \times 10^{4}$ cells per coverslip. While the DNA was complexing, the cells were washed for 5 min with serum-free medium. The complexed DNA mixture was then applied to the coverslips and incubated at $34^{\circ} \mathrm{C}$ for $6 \mathrm{~h}$. The samples were washed with medium supplemented with $10 \% \mathrm{FBS}$ and subsequently incubated at $39^{\circ} \mathrm{C}$ for 1 or $3 \mathrm{~d}$ before fixation. Cells were briefly rinsed three times with $1 \times$ PBS and fixed in freshly prepared $4 \%$ paraformaldehyde in PBS for 20 min at room temperature. After fixation, the cells were washed three times for 5 $\min$ in PBS and stored at $4^{\circ} \mathrm{C}$. Alexa Fluor phalloidin for F-actin staining, performed in accordance with the manufacturer's recommendations (Invitrogen, Eugene, OR), was used during high- $\mathrm{K}^{+}$stimulation to study N19 morphology.

Primary cultures of cortical OL precursor cells. Enriched OL precursors were prepared as described by Amur-Umarjee et al. (1993). First, cerebral hemispheres from 1-d-old mice were mechanically dissociated and plated on poly-D-lysine-coated flasks in DMEM and Ham's F-12 (1:1 v/v) (Invitrogen), containing $100 \mu \mathrm{g} / \mathrm{ml}$ gentamycin and supplemented with $4 \mathrm{mg} / \mathrm{ml}$ dextrose anhydrous, $3.75 \mathrm{mg} / \mathrm{ml} \mathrm{HEPES} \mathrm{buffer,} 2.4 \mathrm{mg} / \mathrm{ml} \mathrm{so-}$ dium bicarbonate, and 10\% FBS (Omega Scientific). After $24 \mathrm{~h}$, the medium was changed, and the cells were grown in DMEM/F-12 supplemented with insulin $(5 \mu \mathrm{g} / \mathrm{ml})$, transferring $(50 \mu \mathrm{g} / \mathrm{ml})$, sodium selenite (30 nM), $\mathrm{T}_{3}(15 \mathrm{~nm})$, D-biotin (10 mM), hydrocortisone (10 nM), 0.1\% BSA (Sigma-Aldrich, St. Louis, MO), 1\% horse serum, and 1\% FBS (Omega Scientific). After 9 d, OLs were purified from the mixed glial culture by the differential shaking and adhesion procedure of Suzumura et al. (1984) and allowed to grow for $24 \mathrm{~h}$ on polylysine-coated coverslips in defined culture medium (Agresti et al., 2005) plus platelet-derived growth factor and basic fibroblast growth factor $(10 \mathrm{ng} / \mathrm{ml})$ (Peprotech, Rocky Hill, NJ).

Cell viability analysis. A trypan blue exclusion assay was used to determine cell viability. After treatment, during different periods of time, with
$20 \mathrm{~mm} \mathrm{~K}^{+}$, cells grown on coverslips for 1 or $3 \mathrm{~d}$ at $39^{\circ} \mathrm{C}$ were incubated in medium containing trypan blue (final concentration, $0.04 \%$ ), for 10 $\min$ at $37^{\circ} \mathrm{C}$. Viable cells were counted in a total of six experiments, four random fields, on triplicate coverslips.

Caspase-3 assay. NucView 488 Caspase-3 substrate, a novel cell membrane-permeable fluorogenic caspase substrate designed for detecting caspase- 3 activity within live cells in real time, was used in accordance with the manufacturer's recommendations (Biotium, Hayward, CA). Briefly, N19 cells grown on coverslips for $1 \mathrm{~d}$ at $39^{\circ} \mathrm{C}$ were incubated in medium containing NucView 488 Caspase- 3 substrate (final concentration, $5 \mu \mathrm{M}$ ) and $20 \mathrm{~mm} \mathrm{~K}{ }^{+}$for $9 \mathrm{~h}$ at $37^{\circ} \mathrm{C}$. Using video microscopy on living N19, Caspase-3-positive cells were counted in a total of four experiments, on four random fields for each time point.

Cell morphology assessment. Process formation of N19 cells was evaluated by estimating the percentage of cells having processes with a length that was equal to or longer than three times the cell-body diameter This method has been used previously for monitoring morphological changes in OL as well as other cell types (Yong et al., 1988, 1991). To obtain the percentage of cells with long processes, fields were randomly chosen on N19-bearing coverslips, and all the GFP-positive cells were determined, as well as the number of N19 cells having processes three times the cell-body diameter, as described previously (Yong et al., 1988, 1991). We used the same experimental procedure to assess the percentage of N19overexpressing golli without processes after high- $\mathrm{K}^{+}$treatment.

Calcium imaging. Methods were similar to those described previously (Colwell, 2000; Michel et al., 2002; Paz Soldan et al., 2003). Briefly, a cooled CCD camera (ORCA-ER; Hamamatsu, Hamamatsu City, Japan) was added to the Olympus (Melville, NY) spinning disc confocal microscope to measure fluorescence. To load the dye into cells, the coverslips were washed in serum and phenol red-free DMEM, and the cells were incubated for $45 \mathrm{~min}$ at $37^{\circ} \mathrm{C}, 5 \% \mathrm{CO}_{2}$ in the same medium containing a final concentration of $4 \mu \mathrm{M}$ fura- 2 AM (TefLabs, Austin, TX) plus $0.08 \%$ pluronic F-127 (Invitrogen), washed four times in DMEM, and stored in DMEM for $0-1 \mathrm{~h}$ before being imaged (Paz Soldan et al., 2003). Resting calcium levels were made in serum-free HBSS containing $2 \mathrm{mM} \mathrm{Ca}^{2+}$ but no $\mathrm{Mg}^{2+}$. Other measurements were made in HBSS. Calcium influx and resting $\mathrm{Ca}^{2+}$ levels were measured on individual cells, and the results were pooled from five separate coverslips representing five separate cells preparations for each condition. The fluorescence of fura- 2 was excited alternatively at wavelengths of 340 and $380 \mathrm{~nm}$ by means of a high-speed wavelength-switching device (Lambda DG-4; Sutter Instruments, Novato, CA). Image analysis software (SlideBook 4.1; Intelligent Imaging Innovations, San Diego, CA) allowed the selection of several "regions of interest" within the field from which measurements are taken. To minimize bleaching, the intensity of excitation light and sampling frequency was kept as low as possible. In these experiments, measurements were normally made once every $2 \mathrm{~s}$.

Calibration of $\mathrm{Ca}^{2+}$ signals. Free $\left[\mathrm{Ca}^{2+}\right]$ was estimated from the ratio $(R)$ of fluorescence at 340 and $380 \mathrm{~nm}$, using the following equation: $\left[\mathrm{Ca}^{2+}\right]=K_{\mathrm{d}} \times$ slope factor $\times\left(R-R_{\min }\right) /\left(R_{\max }-R\right)($ Grynkiewicz et al., 1985). The $K_{\mathrm{d}}$ was assumed to be $140 \mathrm{~nm}$, whereas values for $R_{\min }$ and $R_{\max }$ were all determined via calibration methods. An in vitro method (fura-2 $\mathrm{Ca}^{2+}$ imaging calibration kit; Invitrogen) was used to make estimate values. With this method, glass coverslips were filled with a high$\mathrm{Ca}^{2+}$ (fura-2 plus $10 \mathrm{~mm} \mathrm{Ca}^{2+}$ ), a low-Ca ${ }^{2+}$ (fura-2 plus 10 mm EGTA), and a control solution without fura-2. Each solution also contains a dilute suspension of $15 \mu \mathrm{m}$ of polystyrene microspheres to ensure uniform coverslip/slide separation and facilitate microscope focusing. The fluorescence (F) at $380 \mathrm{~nm}$ excitation of the low- $\mathrm{Ca}^{2+}$ solution was imaged, and the exposure of the camera was adjusted to maximize the signal. These camera settings were then fixed, and measurements were made with 380 and $340 \mathrm{~nm}$ excitation of the three solutions. $R_{\min }=\mathrm{F} 340$ $\mathrm{nm}$ in low $\mathrm{Ca}^{2+} / \mathrm{F} 380$ in low $\mathrm{Ca}^{2+} ; R_{\max }=\mathrm{F} 340$ in high $\mathrm{Ca}^{2+} / \mathrm{F} 380$ in high $\mathrm{Ca}^{2+} ; \mathrm{Sf}=\mathrm{F} 380$ in low $\mathrm{Ca}^{2+} / \mathrm{F} 380$ in high $\mathrm{Ca}^{2+}$.

Correlation analysis. Correlation studies of golli-GFP with $\mathrm{Ca}^{2+}$ influx kinetics were done by confocal microscopy using an Olympus spinning disc confocal equipment. Time-lapse digital images were analyzed using the Pearson's correlation coefficient $(R r)$ facility, which is provided by image analysis software (SlideBook 4.1; Intelligent Imaging Innova- 
tions). $R r$ is a well defined and commonly accepted means for describing the extent of correlation between image pairs. It is a value ranging between -1.0 and 1.0 ; a -1.0 value signifies no correlation, whereas a value of 1.0 signifies perfect correlation (Manders et al., 1993).

Statistical analysis. Data are presented as mean \pm SEM unless noted otherwise. For fura-2, experiment statistical comparison between different experimental groups was performed by analysis of covariance. Measurements of the percentage of trypan blue-positive cells, caspase-3-positive cells, and N19 cells morphology were performed using Student's paired $t$ test, in which $p<0.05$ was defined as statistically significant.

\section{Results}

Cells transfected with golli exhibit increased intracellular

\section{$\mathrm{Ca}^{2+}$ concentrations}

A potentially useful cell line for examining stage-specific effects on OL development is the N19 conditionally immortalized OL line (Verity et al., 1993). This cell line grows and divides at $34^{\circ} \mathrm{C}$, and the cells stop dividing and differentiate further at $39^{\circ} \mathrm{C}$ (nonpermissive temperature). Immunocytochemical and morphological analyses of N19 cells indicate that they represent OLs at immature stages of development. They express markers characteristic of oligodendroglial progenitors (OPs), such as NG2 and A2B5, and do not express MBP or proteolipid protein mRNAs or protein at either the permissive or the nonpermissive temperatures (Foster et al., 1993).

To test the notion that golli proteins play a role in $\mathrm{Ca}^{2+}$ homeostasis in OLs, we transfected N19 cells with golli constructs and examined the effect of depolarization with high $\mathrm{K}^{+}$to induce $\mathrm{Ca}^{2+}$ uptake in the cells. Whole-cell intracellular $\mathrm{Ca}^{2+}$ concentrations were measured in fura-2-loaded N19 cells using an Olympus spinning disc confocal microscope equipped with calcium-imaging software. Images were collected at $2 \mathrm{~s}$ intervals. Under these conditions, intracellular $\mathrm{Ca}^{2+}$ signals were detected when $\mathrm{N} 19$ cells were perfused for $90 \mathrm{~s}$ with $20 \mathrm{mM} \mathrm{K}^{+}$. We found a significant increase in intracellular $\mathrm{Ca}^{2+}$ concentrations in N19 cells overexpressing J37 golli-GFP relative to untransfected control cells. Examples of such measurements are shown in Figure 1.

In an attempt to define the mechanism behind the action of golli on intracellular $\mathrm{Ca}^{2+}$ concentrations and to assess $\mathrm{Ca}^{2+}$ efflux from intracellular stores, we analyzed $\mathrm{Ca}^{2+}$ responses in N19 cells in the presence of caffeine and thapsigargin. Under these experimental conditions, transfected N19 cells did not demonstrate an increase in intracellular $\mathrm{Ca}^{2+}$ concentration compared with controls. We found a significant increase in intracellular $\mathrm{Ca}^{2+}$ only in cells overexpressing golli depolarized with high $\mathrm{K}^{+}$(Fig. $2 A$ ). To assess the role of $\mathrm{Ca}^{2+}$ influx in these experiments, we exposed cultured N19 cells to $\mathrm{Ca}^{2+}$-free medium. Exposure of $\mathrm{N} 19$ cells to high $\mathrm{K}^{+}$in $\mathrm{Ca}^{2+}$-free medium did not lead to any appreciable elevation in $\mathrm{Ca}^{2+}$ compared with controls (Fig. 2A). These data indicate that golli produces its effect through $\mathrm{Ca}^{2+}$ influx, rather than release of $\mathrm{Ca}^{2+}$ from intracellular stores. To determine whether the influx pathway could be inhibited, we exposed N19 cells to $\mathrm{Ni}^{2+}(50 \mu \mathrm{M})$ and $\mathrm{Cd}^{2+}(100 \mu \mathrm{M})$, both specific inhibitors of voltage-operated $\mathrm{Ca}^{2+}$ channels (VOCCs). These divalent cations had a strong effect on the amplitude of the $\mathrm{Ca}^{2+}$ influx in both control and golli-transfected N19 cells, but only $\mathrm{Cd}^{2+}$ completely inhibited the golli effect after treatment with high $\mathrm{K}^{+}$(Fig. 2B). For both ions, a dose-response curve was performed in control N19 cells to select the lowest concentration that produce the maximun inhibitory effect on $\mathrm{Ca}^{2+}$ influx (data not shown).

Cells in the OL lineage exhibit several neuroligand receptors that are linked to $\mathrm{Ca}^{2+}$ homeostasis including the $\alpha$-adrenergic, $\mathrm{H} 1$, muscarinic, ATP, and glutamate receptors (Kastritsis and McCarthy, 1993; Patneau et al., 1994; Takeda et al., 1995). Ligand-induced $\mathrm{Ca}^{2+}$ signals result from receptor-mediated $\mathrm{Ca}^{2+}$ influx, $\mathrm{IP}_{3}$-stimulated intracellular $\mathrm{Ca}^{2+}$ release, or both. To analyze the effect of golli on ligand-gated $\mathrm{Ca}^{2+}$ channels, $\mathrm{Ca}^{2+}$ uptake was stimulated in N19 cells using ATP and glutamate. Our results show a large increase in intracellular $\mathrm{Ca}^{2+}$ after ATP treatment in N19-overexpressing golli, but, in contrast, treatment with glutamate displays no difference versus control (Fig. 2C). Importantly, the ATP-induced $\mathrm{Ca}^{2+}$ uptake was completely abolished in zero $\mathrm{Ca}^{2+}$ or $100 \mu \mathrm{M} \mathrm{Cd}{ }^{2+}$, indicating that this $\mathrm{Ca}^{2+}$ influx is mediated by VOCCs (Fig. 2C).

Using time-lapse confocal $\mathrm{Ca}^{2+}$ imaging, the $\mathrm{Ca}^{2+}$ response was evaluated in cortical OPs obtained from golli KO and WT mice using high $\mathrm{K}^{+}$and glutamate. As expected, the experiment showed a significant decrease in $\mathrm{Ca}^{2+}$ influx induced by high $\mathrm{K}^{+}$ in $\mathrm{KO}$ cultures versus WT OPs (Fig. 2D). On the other hand, the fura-2 ratio of $\mathrm{KO}$ cells responding to glutamate versus WT OPs, as well as in N19 cells transfected with golli, was not significantly different (Fig. 2D). 


\section{Golli-induced sheets and processes are retracted after depolarization with high $\mathrm{K}^{+}$}

Transfection of N19 cells with either golli BG21 or J37 causes the cells to elaborate sheets and processes, but after treating the cells with high $\mathrm{K}^{+}$for $5 \mathrm{~min}, \sim 70 \%$ of the cells transfected with J37 golli-GFP and $\sim 80 \%$ of the cells overexpressing BG21 golli-GFP retracted their processes (Fig. 3A). There was no effect on shamtransfected cells undergoing the same treatment. Importantly, the cells did not retract their sheets and processes when the cells were depolarized in a medium with zero $\mathrm{Ca}^{2+}$ or in the presence of BAPTA-AM, an intracellular $\mathrm{Ca}^{2+}$ chelator (data not shown). In agreement with the previous results, time-lapse confocal microscopy of N19-overexpressing BG21 and J37 golli-GPP shows a fast retraction of sheets and processes at a uniform speed during high- $\mathrm{K}^{+}$perfusion (Fig. 3B, white arrows). Filopodial-like structures were observed during process loss in these experiments (Fig. $3 B$, red arrows).

\section{Retraction of the processes is not attributable to cell death}

To eliminate the possibility that the brief exposure of the transfected $\mathrm{N} 19$ cells to $\mathrm{K}^{+}$reduced the viability of the cells, we examined cell survival as a function of exposure time to $\mathrm{K}^{+}$(5 min to $9 \mathrm{~h}$ ). Cell viability was measured by trypan blue and caspase- 3 staining (Fig. 4). Although there was some increased cell death noted in all treatment groups with time in culture, there was no significant effect observed on the viability of the J37-transfected $\mathrm{N} 19$ cells grown at $39^{\circ} \mathrm{C}$ for $1 \mathrm{~d}$ followed by exposure to high $\mathrm{K}^{+}$ for up to $9 \mathrm{~h}$ (Fig. $4 A, C$ ). Thus, a $5 \mathrm{~min} \mathrm{~K}^{+}$treatment did not cause the cells to die within that time frame, indicating that the rapid retraction of cell processes was attributable to effects on morphological restructuring and not to cell death. Interestingly, if the J37-overexpressing N19 cells were left to mature at $39^{\circ} \mathrm{C}$ for $3 \mathrm{~d}$ and then exposed to high $\mathrm{K}^{+}$, after $6 \mathrm{~h}$ those cells exposed to $\mathrm{K}^{+}$exhibited significantly more cell death than controls (Fig. $4 B)$. Insofar as the length of time the cells are left at the differentiation temperature reflects maturation of the OLs, then these results suggested that more mature OLs might be more susceptible to the effects of high $\mathrm{K}^{+}$in the presence of high levels of golli than immature OLs.

\section{Process retraction results in local increases in intracellular $\mathrm{Ca}^{2+}$ that correlate with sites of high golli concentrations in the cell}

High-resolution spatiotemporal analysis revealed that $\mathrm{Ca}^{2+}$ influx signals were initiated with different latencies at discrete cellular regions and were propagated along the N19 processes and cell body. Figure 5 shows typical time courses of the local changes in intracellular $\mathrm{Ca}^{2+}$ concentration observed in successive time sections of two N19 cells overexpressing J37 golli-GFP after high- $\mathrm{K}^{+}$depolarization. Local $\mathrm{Ca}^{2+}$ influx sites (calcium puffs) in which the response amplitude is higher than in the surrounding areas are evident as red blebs along the processes (Fig. 5, white arrows). In several experiments, we consistently found high correlations between the patterns of local $\mathrm{Ca}^{2+}$ amplitudes and the patterns of golli protein distribution. In particular, cell regions with elevated levels of golli consistently displayed significantly higher-amplitude local $\mathrm{Ca}^{2+}$ signals than were found in surrounding regions (Fig. 6A). Figure $6 B$ shows a single deconvoluted confocal image of a bipolar N19 cell overexpressing golli during high- $\mathrm{K}^{+}$ treatment. It can be clearly seen that golli fluorescence in this cell is predominantly concentrated in multiple high-intensity patches at the growing tips of the processes as well as along the plasma membrane of the cell body. During process retraction, local increases in
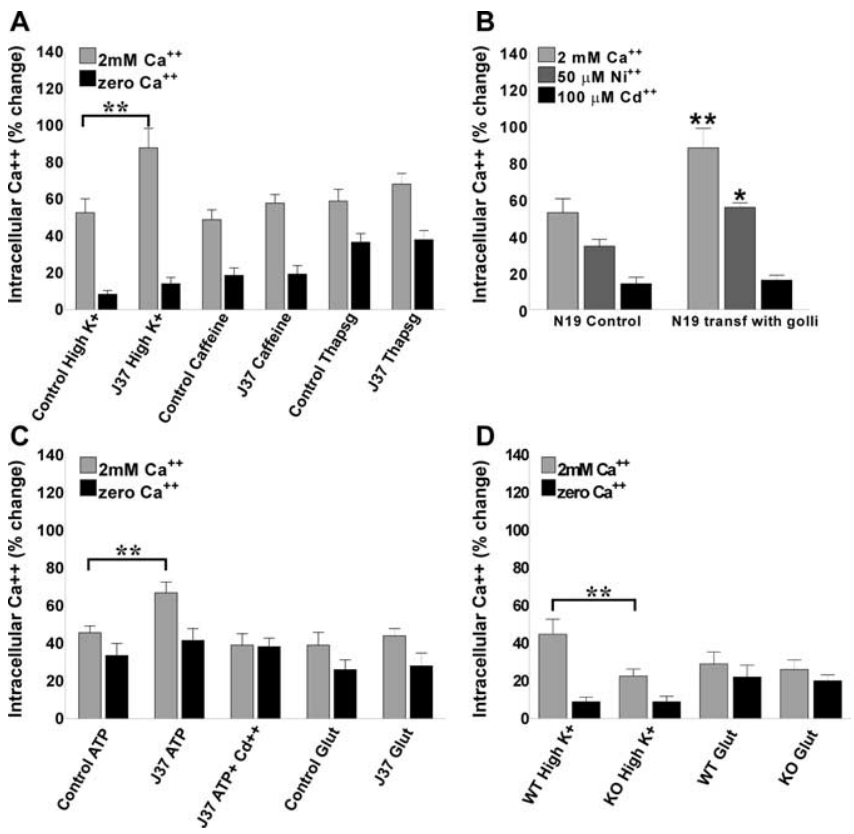

Figure 2. The fura-2 imaging approach was used to evaluate the ability of a number of agonists to elicit a $\mathrm{Ca}^{2+}$ response in $\mathrm{N} 19$ and oligodendroglial cells. The graphs show the average amplitude calculated from the responding cells, expressed as percentage of change of the emission intensities. $\boldsymbol{A}, \mathrm{Ca}^{2+}$ uptake was stimulated in the $\mathrm{N} 19$ cell line using high $\mathrm{K}^{+}(20$ $\mathrm{mm})$, caffeine $(2 \mathrm{~mm})$, and thapsigargin $(100 \mathrm{~nm})$ after culturing the cells $1 \mathrm{~d}$ at $39^{\circ} \mathrm{C}$. These data showed that only the $\mathrm{Ca}^{2+}$ influx induced by high $\mathrm{K}^{+}$was significantly different in N19 cells overexpressing J37 golli-GFP compared with controls. Importantly, these differences in the $\mathrm{Ca}^{2+}$ response between control and overexpressing J37-GFP N19 cells were lost when the cells were in a medium with zero $\mathrm{Ca}^{2+} \cdot \mathrm{B}_{,} \mathrm{Ca}^{2+}$ uptake was stimulated in the $\mathrm{N} 19$ cell line using high $\mathrm{K}^{+}(20 \mathrm{~mm})$ in the presence of $\mathrm{Ni}^{2+}(50 \mu \mathrm{m})$ and $\mathrm{Cd}^{2+}(100 \mu \mathrm{m})$. Note that $\mathrm{Cd}^{2+}$ completely inhibits the golli effect after high-K ${ }^{+}$stimulation. $C$, N19 cells were treated with ATP $(100 \mu \mathrm{m})$ and glutamate $(100 \mu \mathrm{m})$. Note that the ATP-induced $\mathrm{Ca}^{2+}$ uptake was completely abolished in zero $\mathrm{Ca}^{2+}$ or $100 \mu \mathrm{M} \mathrm{Cd}^{2+} . D, \mathrm{Ca}^{2+}$ response was evaluated in cortical $0 \mathrm{Ls}$ from golli $\mathrm{K} 0$ and WT mice using high $\mathrm{K}^{+}(20 \mathrm{~mm})$ and glutamate $(100 \mu \mathrm{m})$. The experiment shows a significant decrease in $\mathrm{Ca}^{2+}$ influx induced by high $\mathrm{K}^{+}$in $\mathrm{KO}$ cultures versus WT 0 Ls. Each agonist was applied for $120 \mathrm{~s}$ by a fast and local perfusion system. Values are expressed as mean \pm SEM of at least six independent experiments. ${ }^{*} p<0.05,{ }^{* *} p<0.01$ versus control. Thapsg, Thapsigargin; Glut, glutamate.

intracellular $\mathrm{Ca}^{2+}$ concentration can be found closely associated with sites of high concentrations of golli (Fig. 6B).

To examine whether the sites of high-density golli protein distribution were related to the sites of high- $\mathrm{Ca}^{2+}$ influx kinetics, we performed correlation experiments between golli-GFP expression and $\mathrm{Ca}^{2+}$ levels in OL processes. We stimulated N19 cells overexpressing golli-GFP with high $\mathrm{K}^{+}$and measured the kinetics of the resulting $\mathrm{Ca}^{2+}$ influx in serial $z$ sections along cell processes. The pattern of golli-GFP fluorescence was then imaged, and the intensities were measured within the same serial sections of the cell in which the $\mathrm{Ca}^{2+}$ influx kinetics were measured. The resultant profile was then compared with the profile of $\mathrm{Ca}^{2+}$ influx kinetics using correlation analysis (see Materials and Methods). In the N19 processes, the Pearson's $R r$ was $0.894 \pm$ $0.021(n=18)$, indicating that there is a significant overlap of golli-GFP and $\mathrm{Ca}^{2+}$ influx sites in the OL processes. A plot of the local $\mathrm{Ca}^{2+}$ amplitudes against the length of the process, together with the intensity of golli-GFP measured in the same cellular sites, showed that the regions with high-intensity golli-GFP corresponded closely with the regions of the process in which the local peak $\mathrm{Ca}^{2+}$ amplitudes were highest (Fig. 6C,D). 
The effect of golli expression on process extension in OL cell lines is mediated through $\mathrm{Ca}^{2+}$ uptake changes

As we have shown here and previously (Reyes and Campagnoni, 2002), overexpression of golli proteins in OL cell lines can induce the elaboration of processes and membrane sheets in the transfected cells. Several studies have indicated the importance of $\mathrm{Ca}^{2+}$ in OL process extension (Pende et al., 1997; Stariha et al., 1997; Yoo et al., 1999). Because increased levels of both golli and intracellular $\mathrm{Ca}^{2+}$ levels lead to process outgrowth in OLs, we examined the possibility that the golli effect on process extension was mediated through $\mathrm{Ca}^{2+}$ changes. Accordingly, N19 cells were exposed to three concentrations $(5,10$, and $20 \mu \mathrm{M})$ of BAPTA-AM, an intracellular $\mathrm{Ca}^{2+}$ chelator, for $2 \mathrm{~d}$ at $39^{\circ} \mathrm{C}$. Process extension was evaluated by determining the percentage of transfected N19 cells with processes that had a length either equal to or greater than three times the mean cell-body diameter of the N19 population. Figure $7 A$ shows that there was a negative correlation between the presence of BAPTA in the medium and the percentage of transfected N19 cells with processes longer than three times the cell-body diameter. In control medium, transfected N19 cells with long processes comprised $\sim 50 \%$ of the population. As the concentration of BAPTA was increased, there was a reduction in the percentage of these cells. For example, at a BAPTA concentration of $10 \mu \mathrm{M}$, the percentage of transfected N19 cells with long processes was only about half of those grown in control medium (Fig. 7A). In the presence $20 \mu \mathrm{M}$ BAPTA, there was essentially complete inhibition of N19 process extension; although at this concentration we noted some cell death (data not shown). In the presence of $\mathrm{Cd}^{2+}$, a specific VOCC blocker, there was strong inhibition of the elaboration of processes and membrane sheets induced by golli in N19 cells (Fig. 7B). Figure 7C illustrates fluorescent images of N19 cells transfected with either the control GFP vector or the J37 golli-GFP construct at $39^{\circ} \mathrm{C}$. No morphological changes were induced in N19 cells transfected with the control GFP vector, and the cells retained the appearance of nontransfected cells (Fig. 7Ca). After these cells were transfected with the J37 golli-GFP construct, the N19 cells generally flattened elaborated large processes (Fig. 7Cb). Interestingly, this phenomenon disappeared in the presence of 50 or 100 $\mu \mathrm{m} \mathrm{Cd}{ }^{2+}$ (Fig. $7 C c, C d$ ), indicating that the morphological changes induced by golli could be mediated by VOCCs.

A structural relationship between the effects of golli on $\mathrm{Ca}^{2+}$ uptake and OL process retraction

To identify any motifs on the golli protein that might be important in the effects of golli on process extension/retraction, we prepared mutated/deleted versions of J37 and BG21 fused to GFP. The GFP-mutated golli plasmids were transfected into $\mathrm{N} 19$ cells and $\mathrm{Ca}^{2+}$ transients measured to determine what sites on the molecule might be important for $\mathrm{Ca}^{2+}$ regulation. Figure $8 \mathrm{~A}$ shows a diagram of the mutations/deletions generated for analysis. We found that elimination of the first 45 or 110 amino acids from the $\mathrm{N}$ terminus of J37 (J37 Del1 and J37 Del2, respectively) completely obliterated the $\mathrm{Ca}^{2+}$ influx increase (Fig. 8 B). Feng et al. (2006) found that myristoylation of the glycine residue at the $\mathrm{N}$ terminus of golli BG21 was important for targeting golli to the plasma membrane in the Jurkat T-cell line. In the present study, we confirmed that mutation of the myristoylation sites (gly $\rightarrow$ ala at position 2 ) of either golli J37 or BG21 (J37 and BG21 Myrist) completely reversed the $\mathrm{Ca}^{2+}$ effect in an OL line, indicating that membrane association is essential for golli action on the enhancement of $\mathrm{Ca}^{2+}$ entry in OLs (Fig. $8 \mathrm{~B}$ ). Additionally, deleting a calmodulin-binding-like site (J37 NoCalmod) and a prolinerich domain (J37 Del3) within the J37 golli domain reduced 

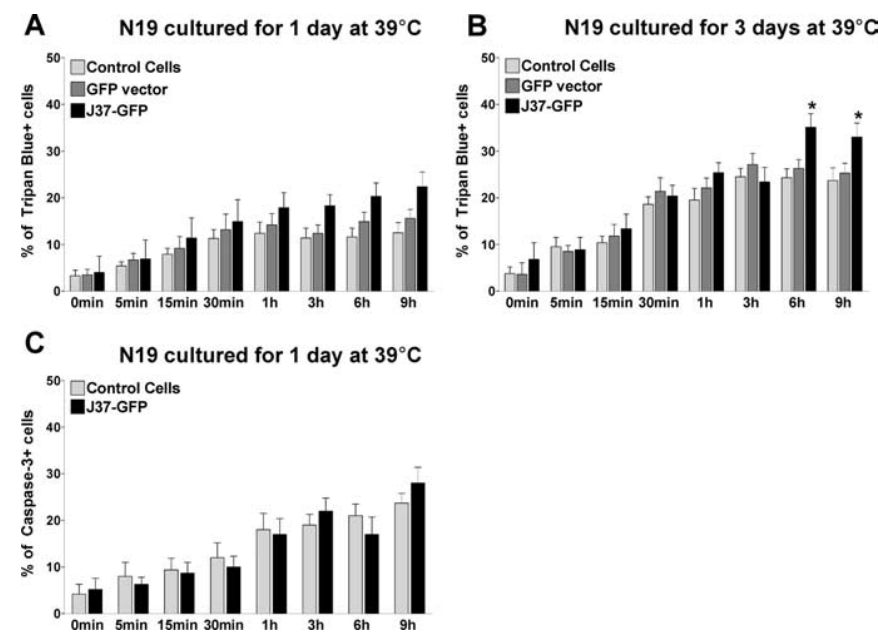

Figure 4. $\quad A, B$, N19 cells transfected with J37 golli-GFP (J37-GFP), nonmodified GFP vector, and untransfected cells (Control cells) were cultured for $1 \mathrm{~d}(\boldsymbol{A})$ and $3 \mathrm{~d}(\boldsymbol{B})$ at $39^{\circ} \mathrm{C}$. The cells were treated with $20 \mathrm{~mm} \mathrm{~K}^{+}$for the times indicated, and the percentage of trypan blue-positive cells was determined. Only J37-overexpressing N19 cells cultured for $3 \mathrm{~d}$ at $39^{\circ} \mathrm{C}$ followed by high- $K^{+}$treatment for $\geq 6$ h exhibited significantly more cell death than controls. The results are expressed as mean \pm SEM of two independent experiments, with duplicate cultures for each time point. ${ }^{*} p<0.05$ versus control. C, N19 cells cultured for $1 \mathrm{~d}$ at $39^{\circ} \mathrm{C}$ were treated with $20 \mathrm{~mm} \mathrm{~K}^{+}$for $9 \mathrm{~h}$. Using NucView 488 Caspase-3 substrate and time-lapse microscopy, the percentage of Caspase-3-positive cells was determined in each time point. The results are expressed as mean \pm SEM of four independent experiments.

the effect by $\sim 30$ and $\sim 20 \%$, respectively (Fig. 8 B). Note that these studies on $\mathrm{Ca}^{2+}$ influx after high-K ${ }^{+}$stimulation correlate completely with the results obtained on the effects of transfected golli on cell morphology and process loss (Fig. $8 C, D)$. This correlation implies a clear relationship between golli, $\mathrm{Ca}^{2+}$ uptake, and process extension/retraction.

\section{Discussion}

The functions of the golli MBPs are only just beginning to be understood. One property of golli proteins is their ability to induce extension of processes when overexpressed in OL lines (Reyes and Campagnoni, 2002) and in PC12 cells (Feng et al., 2004). Jurkat T-cells transfected with golli exhibit significantly altered $\mathrm{Ca}^{2+}$ homeostasis in vitro (Feng et al., 2006), and $\mathrm{Ca}^{2+}$ uptake in both OLs and T-cells is disturbed in golli $\mathrm{KO}$ mice (Feng et al., 2006; Jacobs et al., 2005). Changes in $\left[\mathrm{Ca}^{2+}\right]_{\text {int }}$ appear to play a critical role in the ability of OLs to maintain processes and membrane sheets in vitro (Benjamins and Nedelkoska, 1996; Marta et al., 2005). To determine the relationship between golli, $\mathrm{Ca}^{2+}$ homeostasis, and OL process formation/maintenance, we took advantage of the fact that transfection of golli into N19 OLs induces process/sheet formation and an observation, described here, that depolarization of these transfected cells with high $\mathrm{K}^{+}$caused retraction of those processes.

Golli overexpression in N19 cells induced to extend processes and sheets is associated with increased $\left[\mathrm{Ca}^{2+}\right]_{\text {int }}$ in the cells Several lines of evidence indicate that the effects of golli overexpression on process extension/maintenance in OLs are mediated through $\mathrm{Ca}^{2+}$ changes: (1) $\mathrm{Ca}^{2+}$ uptake mediated by VOCCs increases significantly in N19 cells transfected with either golli BG21 or J37 after high- $\mathrm{K}^{+}$treatment; (2) membrane depolarization in transfected N19 cells results in process/sheet retraction, and this is not observed in medium con- taining $0 \mathrm{Ca}^{2+}$; and (3) pretreatment of transfected N19 cells with BAPTA-AM (an intracellular $\mathrm{Ca}^{2+}$ chelator) or $\mathrm{Cd}^{2+}(\mathrm{a}$ specific VOCC blocker) results in a dose-dependent reduction in process extension.

How can $\mathrm{Ca}^{2+}$ influx through VOCCs evoke both positive and negative process remodeling responses (i.e., process extension and retraction)? A stimulus that causes a small increase in the open probability of $\mathrm{Ca}^{2+}$ channels will give rise to a condition in which individual channels spend submilliseconds open. Targets located close to the channels will experience a brief but intense $\left[\mathrm{Ca}^{2+}\right]$ increase in the short period the channel is open. Bolsover (2005) suggests that $\mathrm{Ca}^{2+}$-sensitive sites that evoke processes elongation are located close to VOCCs. In contrast, membrane depolarization (e.g., high $\mathrm{K}^{+}$) causes a large increase in $\mathrm{Ca}^{2+}$ channel open probability leading to a significant increase of $\left[\mathrm{Ca}^{2+}\right]$ at locations remote from the channel, producing actin depolymerization and/or process collapse. Thus, high levels of golli result in modest elevations in $\mathrm{Ca}^{2+}$ influx, possibly generated by VOCCs, and cause process extension, whereas higher levels of $\left[\mathrm{Ca}^{2+}\right]_{\text {int }}$ are induced by membrane depolarization, resulting in the retraction of processes.

\section{Binding of golli to the plasma membrane is essential for modulating $\mathrm{Ca}^{2+}$ homeostasis}

Golli proteins can bind several molecules important in $\mathrm{Ca}^{2+}$ signaling. Kaur et al. (2003) and Feng et al. (2006) found that myristoylation of BG21 is essential for the interaction of golli with the plasma membrane in T-cells. In this study, we found that mutating the myristoylation site completely obliterated the $\mathrm{Ca}^{2+}$ response and deleting portions of the golli domain in J37 containing these potential signaling sites (e.g., a putative calmodulin-binding-like site) reduced the $\mathrm{Ca}^{2+}$ response. These data suggest that binding of golli to the plasma membrane is essential for modulating $\mathrm{Ca}^{2+}$ homeostasis but that other types of interactions are also important, although not as essential.

\section{Cells overexpressing golli exhibit increased $\mathrm{Ca}^{2+}$ influx after membrane depolarization}

The predominant mechanism for $\mathrm{Ca}^{2+}$ signaling in OLs is via $\mathrm{IP}_{3}$ receptor-mediated efflux from endoplasmic reticulum (ER) intracellular stores in response to G-protein-coupled receptor activation of phospholipase C (James and Butt, 2002; Kirischuk et al., 1995; Takeda et al., 1995). However, $\mathrm{Ca}^{2+}$ influx across the OL plasma membrane also can occur through a number of other routes: (1) $\mathrm{Ca}^{2+}$ can enter directly through a number of ligandoperated channels; (2) calcium can enter through VOCCs, activated in response to cell membrane depolarization, such as raised extracellular $\mathrm{K}^{+}$; and (3) depletion of ER stores can result in the opening of store-operated $\mathrm{Ca}^{2+}$ channels (Simpson et al., 1997, 1998; Deitmer et al., 1998; Belachew et al., 2000; Alberdi et al., 2005).

We analyzed $\mathrm{Ca}^{2+}$ responses in N19 cells using several agonists to activate different mechanisms that generate $\mathrm{Ca}^{2+}$ signaling in OLs. High extracellular $\mathrm{K}^{+}$activates $\mathrm{Ca}^{2+}$ influx through VOCCs, and caffeine and thapsigargin mediate $\mathrm{Ca}^{2+}$ efflux from ER intracellular stores. In the golli-transfected cells, we found a significant increase in $\left[\mathrm{Ca}^{2+}\right]_{\text {int }}$ only after high- $\mathrm{K}^{+}$stimulation. Importantly, this increase was dependent on $\mathrm{Ca}^{2+}$ in the medium, indicating that golli produces its effect through $\mathrm{Ca}^{2+}$ influx, rather than $\mathrm{Ca}^{2+}$ release from intracellular stores. 
The ability of metal ions to block VOCCs is well established (Kostyuk and Krishtal, 1977; Lansman et al., 1986). We found that $\mathrm{Ni}^{2+}$ and $\mathrm{Cd}^{2+}$ blocked $\mathrm{Ca}^{2+}$ influx in both control and gollioverexpressing $\mathrm{N} 19$ cells, but only $\mathrm{Cd}^{2+}$ completely inhibited the golli-induced $\mathrm{Ca}^{2+}$ effect after high-K ${ }^{+}$stimulation. $\mathrm{Cd}^{2+}$ ions block all VOCCs, but $\mathrm{Ni}^{2+}$ has been reported to be more specific to T-type calcium channels (Fox et al., 1987; Tottene et al., 1996; Lee et al., 1999).

Cultured OLs have exhibited a developmental regulation of $\mathrm{L}-, \mathrm{N}-$, and R-type VOCC expression (Blankenfeld et al., 1992; Agrawal et al., 2000; Chen et al., 2000), and recent findings suggest that VOCCs are concentrated on OL processes (Agrawal et al., 2000; Chen et al., 2000). These data are consistent with our finding of colocalization of golli proteins and "hot spots" of $\mathrm{Ca}^{2+}$ influx along OL processes.

OLs can exhibit $\mathrm{Ca}^{2+}$ responses to ATP (Kirischuk et al., 1995; Takeda et al., 1995), either through P2X receptors, which are ligand-gated, nonselective $\mathrm{Ca}^{2+}$ channels, or through $\mathrm{P} 2 \mathrm{Y}$ receptors, which are metabotropic receptors linked to G-protein activation and to $\mathrm{IP}_{3}$-dependent $\mathrm{Ca}^{2+}$ release (von Kugelgen and Wetter, 2000; Khakh et al., 2001). ATP receptor-mediated $\mathrm{Ca}^{2+}$ signaling in OLs is initiated by increased influx of $\mathrm{Na}^{+}$and $\mathrm{Ca}^{2+}$ through the activated receptor. Subsequently, $\mathrm{Na}^{+}$influx can trigger a secondary increase in the $\left[\mathrm{Ca}^{2+}\right]_{\text {int }}$ through VOCCs. Our results indicate that, in N19 cells, the ATPevoked increase in intracellular $\mathrm{Ca}^{2+}$ is mediated predominantly via metabotropic receptors, but with a significant ionotropic component. This was demonstrated by removal of extracellular $\mathrm{Ca}^{2+}$ and a reduction in the $\mathrm{Ca}^{2+}$ response. Additionally, incubation of N19 cells in $100 \mu \mathrm{M} \mathrm{Cd}^{2+}$ completely blocked the ATP-evoked $\mathrm{Ca}^{2+}$ influx increase in N19 cells overexpressing golli, indicating a key contribution of VOCCs.

Glutamate also activates ionotropic receptors, which gate membrane ion channels permeable to $\mathrm{Ca}^{2+}$, and metabotropic receptors, which are coupled to G-proteins (Dingledine et al., 1999). Ionotropic glutamate receptors (i.e., AMPA/ kainate) are expressed by OLs and OPs (McDonald et al., 1998; Sanchez-Gomez and Matute, 1999). We found no significant differences in intracellular $\mathrm{Ca}^{2+}$ responses between control and N19 gollitransfected cells or golli KO and WT OPs,
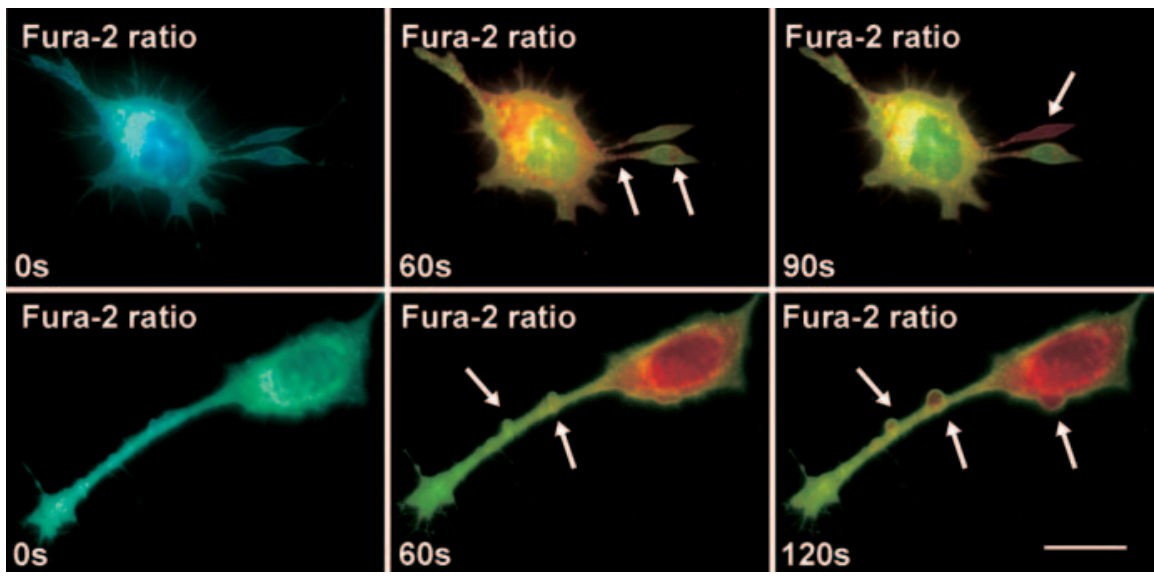

Figure 5. Time-lapse confocal microscopy of $\mathrm{N} 19$ cells overexpressing J37 golli-GPP grown for $1 \mathrm{~d}$ at $39^{\circ} \mathrm{C}$ and treated with 20 $\mathrm{mm} \mathrm{K}^{+}$for $120 \mathrm{~s}$. An increased fura-2 fluorescence ratio is indicated by warmer colors. Local $\mathrm{Ca}^{2+}$ influx sites (calcium puffs) are visible as red blobs. Note that $\mathrm{Ca}^{2+}$ transients initiate with different latencies in different cellular sites and specialized regions in which the response amplitude is higher than in surrounding areas are evident (arrows) along the processes. Scale bar, $10 \mu \mathrm{m}$.
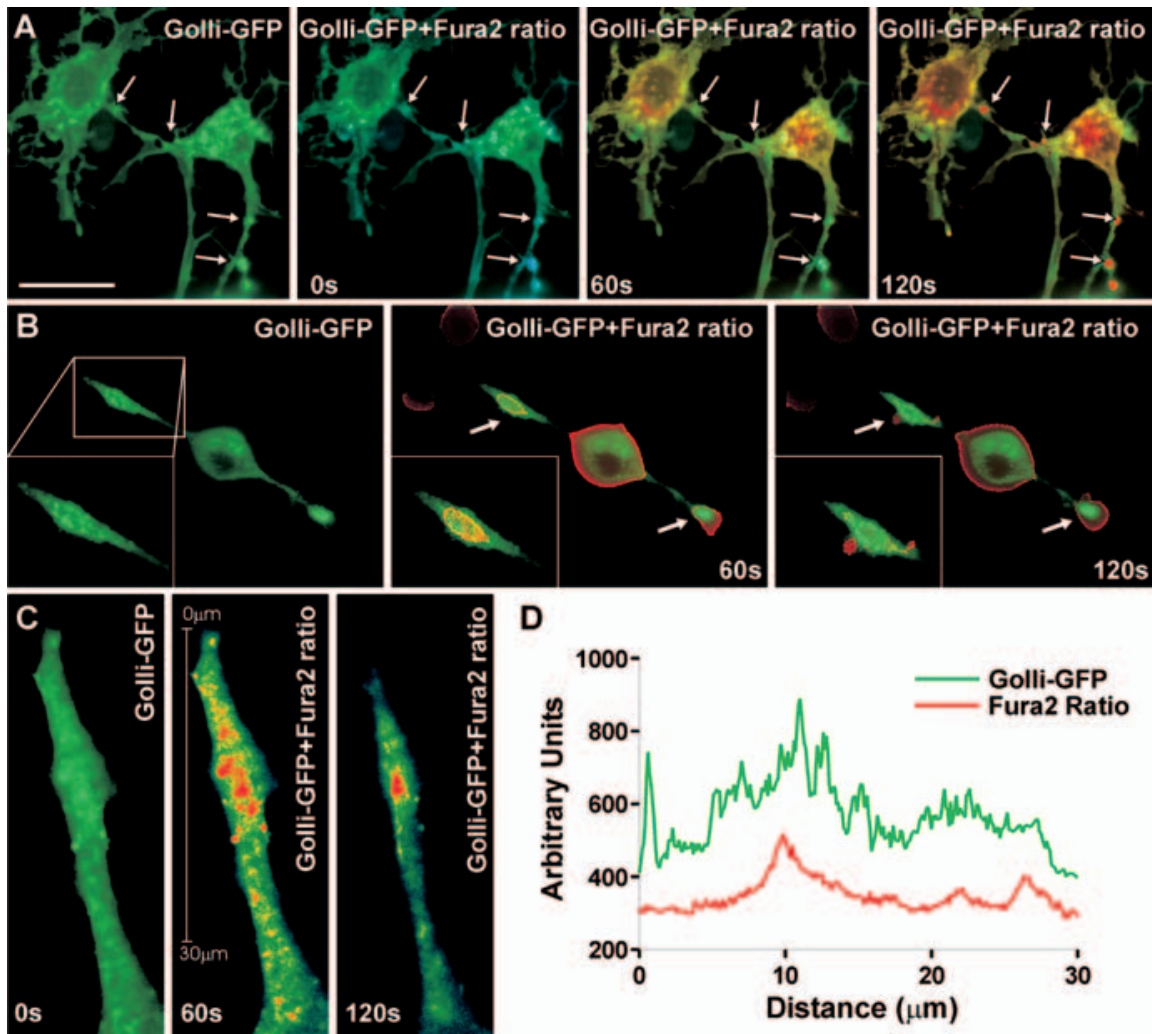

Figure 6. Time-lapse confocal microscopy of $\mathrm{N} 19$ cells overexpressing $\mathrm{J} 37$ golli-GPP grown for $1 \mathrm{~d}$ at $39^{\circ} \mathrm{C}$ and treated with 20

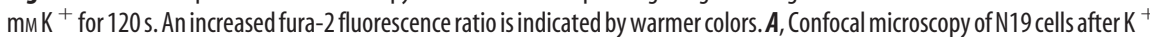
stimulation reveals a close association between golli and local $\mathrm{Ca}^{2+}$ influx sites (arrows). $\boldsymbol{B}$, Four serial optical sections (every 0.09 $\mu \mathrm{m}$ in the $z$-dimension) were obtained for this deconvoluted image from a region just above the nucleus of the cell. Note that golli fluorescence in this $\mathrm{N} 19$ bipolar cell is predominantly concentrated in multiple high-intensity patches at the process growing tips. Local increases in intracellular $\mathrm{Ca}^{2+}$ concentration are found closely associated with these sites of high concentrations of golli (arrows) during processes retraction. C, Time-lapse confocal microscopy of N19 cell process overexpressing J37 golli-GPP during high- $\mathrm{K}^{+}$treatment. Peaks in local amplitude of $\mathrm{Ca}^{2+}$ uptake were found at several sites along the process. The close interrelationship between golli and $\mathrm{Ca}^{2+}$ influx sites can be clearly seen, with golli-GFP being closely surrounded by high levels of fura- 2 ratio. $D$, Correlation analysis of the patterns of local peak $\mathrm{Ca}^{2+}$ amplitudes and golli-GFP in the same N19 process shown in C. Local peak $\mathrm{Ca}^{2+}$ amplitudes after $60 \mathrm{~s}$ of high-K ${ }^{+}$stimulation (red line) along the process are shown compared with golli-GFP fluorescence measurement (green line) in the same cellular sections. Scale bar, (in A) $10 \mu \mathrm{m}$. 
A

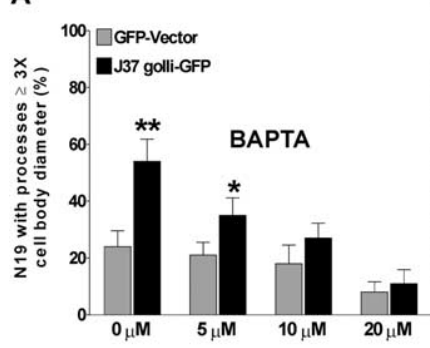

B

C

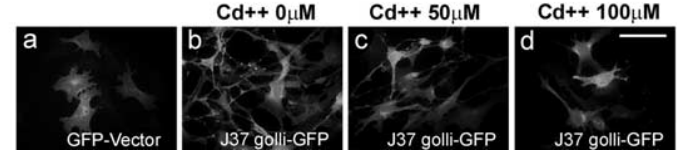

Figure 7. Effect of $\mathrm{Ca}^{2+}$ chelator (BAPTA-AM) and $\mathrm{Cd}^{2+}$ on N19 process extension. $\boldsymbol{A}, \boldsymbol{B}$, The percentage of N19 cells overexpressing J37 golli-GFP with processes greater or equal to three times the cell-body diameter is indicated as a function of the concentration of BAPTA $(\boldsymbol{A})$ or $\mathrm{Cd}^{2+}(\boldsymbol{B})$ used in the incubation medium. Values are expressed as mean $\pm \mathrm{SEM}$ of at least four independent experiments. ${ }^{*} p<0.05,{ }^{* *} p<0.01$ versus cells transfected with nonmodified GFP vector. C, Elaboration of processes in the N19 cells transfected with J37 golli-GFP. Fluorescent images of an $\mathrm{N} 19$ cell transfected with the nonmodified GFP vector did not undergo any dramatic changes in cell morphology $(\boldsymbol{a})$, whereas cells transfected with the full-length J37 appeared broader and had elaborated extensive processes $(\boldsymbol{b})$. However, the presence of $\mathrm{Cd}^{2+}$ (50 or $100 \mu \mathrm{m}$ ) in the culture medium completely inhibits the golli effect on N19 morphology (c, d). Scale bar, $30 \mu \mathrm{m}$.

A
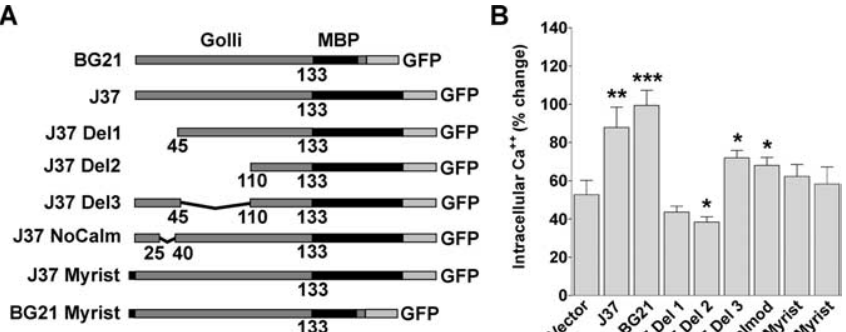

C
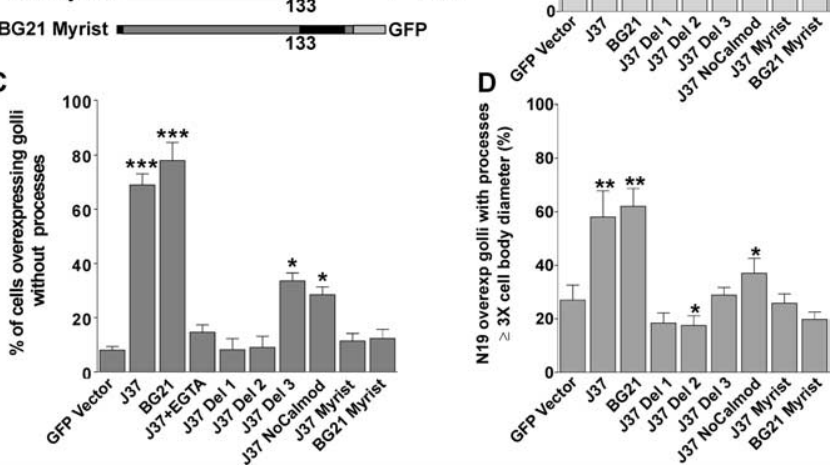

Figure 8. $\quad \boldsymbol{A}$, Diagrammatic scheme of the golli-mbp::GFP constructs designed to examine the regions on golli protein that might be responsible for the increase in $\mathrm{Ca}^{2+}$ influx in the glial cell lines. The golli protein was divided into the MBP and golli domain to determine whether either regions were responsible for the increase in $\mathrm{Ca}^{2+}$ uptake. Expression of the insert is under the cytomegalovirus promoter. $\boldsymbol{B}, \mathrm{Ca}^{2+}$ uptake was stimulated in $\mathrm{N} 19$ cells overexpressing different golli-GPP constructs using high $\mathrm{K}^{+}(20 \mathrm{~mm})$ after culturing the cells for $1 \mathrm{~d}$ at $39^{\circ} \mathrm{C}$. High $\mathrm{K}^{+}$was applied to $\mathrm{N} 19$ cells for 120 s by a fast and local perfusion system. The graph shows the average amplitude calculated from the responding cells, expressed as the percentage of change of the emission intensities. C, Quantitative analysis of process retraction in N19 cells overexpressing different golli-GPP constructs after 5 min with $20 \mathrm{~mm} \mathrm{~K}^{+}$. D, Quantitative analysis of process formation in N19 cells transfected with different golli-GPP constructs and cultured for $1 \mathrm{~d}$ at $39^{\circ} \mathrm{C}$. Note that the analysis of $\mathrm{Ca}^{2+}$ influx after high- $\mathrm{K}^{+}$stimulation show a strong correlation with the results obtained on cell morphology (process retraction and extension). Values are expressed as mean \pm SEM of at least four independent experiments. ${ }^{*} p<0.05,{ }^{* *} p<$ $0.01,{ }^{* * *} p<0.001$ versus cells transfected with nonmodified GFP vector. suggesting that golli is not affecting ionotropic or metabotropic glutamate receptors. These data support the notion that golli proteins modulate VOCCs in OLs.

\section{Depolarization of N19 cells overexpressing golli leads to destabilization and retraction of sheets and processes}

The retraction of processes in the depolarized N19 cells overexpressing golli was not attributable to the induction of cell death as assessed by trypan blue and caspase- 3 assays for up to $9 \mathrm{~h}$ of exposure to depolarizing conditions. Interestingly, as soon as the high $\mathrm{K}^{+}$was removed from the extracellular medium, the N19 cells started to regenerate their processes and sheaths.

High-resolution spatiotemporal analysis revealed that $\mathrm{Ca}^{2+}$ influx in N19 cells overexpressing golli initiated with different latencies at discrete cellular locations. During process retraction, subcellular regions with elevated golli levels consistently displayed higher-amplitude $\mathrm{Ca}^{2+}$ signals than were found in surrounding areas. Changes in $\left[\mathrm{Ca}^{2+}\right]_{\text {int }}$ play a critical role in the ability of OLs to maintain membrane sheets and processes. Benjamins and Nedelkoska (1996) found that longer exposure to A23187 ( $\mathrm{Ca}^{2+}$ ionophore) or thapsigargin lead to membrane sheet retraction and eventual cell death in rat OLs. Our results indicate that mouse N19 gollioverexpressing cells can survive a prolonged influx of $\mathrm{Ca}^{2+}$, but these cells do not have a mechanism to avoid the cytoskeletal disruption.

The findings described here suggest a key role for golli proteins in the regulation of $\mathrm{OL} \mathrm{Ca}{ }^{2+}$ homeostasis, which is distinct from the role of the classic MBPs. It has been reported that classic MBP and MBP peptides (1-44 and 88-151) interact with ganglioside GM1, and this interaction can lead to an increase $\mathrm{Ca}^{2+}$ influx in OLs (Tzeng et al., 1995). However, previous transfection with the BG21 MBP domain studies showed no morphological changes (Reyes and Campagnoni, 2002), and there are no $\mathrm{Ca}^{2+}$ changes associated with transfection of the J37 MBP domain into N19 cells (our unpublished data). Note that the golli domain contains a binding site for monosialogangliosides and the deletion of this region results in a reduction of the $\mathrm{Ca}^{2+}$ effect in N19 cells. Thus, it is likely that the golli forms of the MBP are responsible for regulating $\mathrm{Ca}^{2+}$ homeostasis in the oligodendrocyte, which is a property of the golli domain on the molecule.

\section{References}

Agrawal SK, Nashmi R, Fehlings MG (2000) Role of L- and N-type calcium channels in the pathophysiology of traumatic spinal cord white matter injury. Neuroscience 99:179-188.

Agresti C, Meomartini ME, Amadio S, Ambrosini E, Serafini B, Franchini L, Volonte C, Aloisi F, Visentin S (2005) Metabotropic P2 receptor activation regulates oligodendrocyte progenitor migration and development. Glia 50:132-144.

Alberdi E, Sanchez-Gomez MV, Matute C (2005) Calcium and glial cell death. Cell Calcium 38:417-425.

Amur-Umarjee S, Phan T, Campagnoni AT (1993) Myelin basic protein mRNA translocation in oligodendrocytes is inhibited by astrocytes in vitro. J Neurosci Res 36:99-110.

Belachew S, Malgrange B, Rigo JM, Rogister B, Leprince P, Hans G, Nguyen L, Moonen G (2000) Glycine triggers an intracellular calcium influx in oligodendrocyte progenitor cells which is mediated by the activation of both the ionotropic glycine receptor and $\mathrm{Na}^{+}$-dependent transporters. Eur J Neurosci 12:1924-1930.

Benjamins JA, Nedelkoska L (1996) Release of intracellular calcium stores leads to retraction of membrane sheets and cell death in mature mouse oligodendrocytes. Neurochem Res 21:471-479. 
Blankenfeld G, Verkhratsky A, Kettenmann H (1992) $\mathrm{Ca}^{++}$channels expression in the oligodenroglial lineage. Eur J Neurosci 4:1935-1948.

Bolsover SR (2005) Calcium signalling in growth cone migration. Cell Calcium 37:395-402.

Campagnoni AT, Pribyl TM, Campagnoni CW, Kampf K, Amur-Umarjee S, Landry CF, Handley VW, Newman SL, Garbay B, Kitamura K (1993) Structure and developmental regulation of Golli-mbp, a 105 $\mathrm{kb}$ gene that encompasses the myelin basic protein gene and is expressed in cells in the oligodendrocyte lineage in the brain. J Biol Chem 268:4930-4938.

Chen S, Ren YQ, Bing R, Hillman DE (2000) alE subunit of the R-type calcium channel is associated with myelinogenesis. J Neurocytol 29:719-728.

Colwell CS (2000) Circadian modulation of calcium levels in cells in the suprachiasmatic nucleus. Eur J Neurosci 12:571-576.

Deitmer JW, Verkhratsky AJ, Lohr C (1998) Calcium signaling in glial cells. Cell Calcium 24:405-416.

Dingledine R, Borges K, Bowie D, Traynelis SF (1999) The glutamate receptor ion channels. Pharmacol Rev 51:7-61.

Feng JM, Givogri IM, Bongarzone ER, Campagnoni C, Jacobs E, Handley VW, Schonmann V, Campagnoni AT (2000) Thymocytes express the golli products of the myelin basic protein gene and levels of expression are stage dependent. J Immunol 165:5443-5450.

Feng JM, Campagnoni CW, Hu YH, Kampf K, Schonmann V, Campagnoni AT (2004) Golli product of myelin basic protein gene promotes process formation in neuronal cells. Soc Neurosci Abstr 30:36.1.

Feng JM, Hu YK, Xie LH, Colwell CS, Shao XM, Sun XP, Chen B, Tang H, Campagnoni AT (2006) Golli protein negatively regulates store depletion-induced calcium influx in T cells. Immunity 24:717-727.

Foster LM, Phan T, Verity AM, Bredesen D, Campagnoni AT (1993) Generation and analysis of normal and shiverer temperature-sensitive immortalized cell lines exhibiting phenotypic characteristics of oligodendrocytes at several stages of differentiation. Dev Neurosci 15:100-109.

Fox AP, Nowycky MC, Tsien RW (1987) Single-channel recordings of three types of calcium channels in chick sensory neurones. J Physiol (Lond) 394:173-200.

Grynkiewicz G, Poenie M, Tsien RY (1985) A new generation of $\mathrm{Ca}^{++}$indicators with greatly improved fluorescence properties. J Biol Chem 260:3440-3450.

Jacobs EC, Pribyl TM, Feng JM, Kampf K, Spreuer V, Campagnoni C, Colwell CS, Reyes SD, Martin M, Handley V, Hiltner TD, Readhead C, Jacobs RE, Messing A, Fisher RS, Campagnoni AT (2005) Region-specific myelin pathology in mice lacking the golli products of the myelin basic protein gene. J Neurosci 25:7004-7013.

James G, Butt AM (2002) P2Y and P2X purinoceptor mediated $\mathrm{Ca}^{++}$signalling in glial cell pathology in the central nervous system. Eur J Pharmacol 447:247-260.

Kastritsis CH, McCarthy KD (1993) Oligodendroglial lineage cells express neuroligand receptors. Glia 8:106-113.

Kaur J, Libich DS, Campagnoni CW, Wood DD, Moscarello MA, Campagnoni AT, Harauz G (2003) Expression and properties of the recombinant murine Golli-myelin basic protein isoform J37. J Neurosci Res 71:777-784.

Khakh B, Burnstock G, Kennedy C, King BF, North RA, Seguela P, Voigt M, Humphrey PPA (2001) Current status of the nomenclature and properties of P2X receptors and their subunits. International Union of Pharmacology. XXIV. Pharmacol Rev 53:107-118.

Kirischuk S, Scherer J, Kettenmann H, Verkhratsky A (1995) Activation of $\mathrm{P} 2$ purinoreceptors triggered $\mathrm{Ca}^{++}$release from InsP3-sensitive internal stores in mammalian oligodendrocytes. J Physiol (Lond) 483:41-57.

Kostyuk PG, Krishtal OA (1977) Effects of calcium and calcium-chelating agents on the inward and outward current in the membrane of mollusc neurones. J Physiol (Lond) 270:569-580.

Landry CF, Ellison JA, Pribyl TM, Campagnoni C, Kampf K, Campagnoni AT (1996) Myelin basic protein gene expression in neurons: developmental and regional changes in protein targeting within neuronal nuclei, cell bodies, and processes. J Neurosci 16:2452-2462.

Landry CF, Ellison J, Skinner E, Campagnoni AT (1997) Golli-mbp proteins mark the earliest stages of fiber extension and terminal arboration in the mouse peripheral nervous system. J Neurosci Res 50:265-271.
Landry CF, Pribyl TM, Ellison JA, Givogri MI, Kampf K, Campagnoni CW, Campagnoni AT (1998) Embryonic expression of the myelin basic protein gene: identification of a promoter region that targets transgene expression to pioneer neurons. J Neurosci 18:7315-7327.

Lansman JB, Hess P, Tsien RW (1986) Blockade of current through single calcium channels by $\mathrm{Cd}^{++}, \mathrm{Mg}^{++}$, and $\mathrm{Ca}^{++}$. Voltage and concentration dependence of calcium entry into the pore. J Gen Physiol $88: 321-347$.

Lee JH, Gomora JC, Cribbs LL, Perez-Reyes E (1999) Nickel block of three cloned T-type calcium channels: low concentrations selectively block alpha1H. Biophys J 77:3034-3042.

Manders MM, Verbeek FJ, Aten JA (1993) Measurement of co-localization of objects in dual-color confocal images. J Microsc 169:375-382.

Marta CB, Montano MB, Taylor CM, Taylor AL, Bansal R, Pfeiffer SE (2005) Signaling cascades activated upon antibody cross-linking of myelin oligodendrocyte glycoprotein: potential implications for multiple sclerosis. J Biol Chem 280:8985-8993.

Martin M, Reyes SD, Hiltner TD, Givogri MI, Tyszka JM, Fisher R, Campagnoni AT, Fraser SE, Jacobs RE, Readhead C (2007) T(2)-weighted microMRI and evoked potential of the visual system measurements during the development of hypomyelinated transgenic mice. Neurochem Res 32:159-165.

McDonald JW, Althomsons SP, Hyrc KL, Choi DW, Goldberg MP (1998) Oligodendrocytes from forebrain are highly vulnerable to AMPA/kainate receptor-mediated excitotoxicity. Nat Med 4:291-297.

Michel S, Itri J, Colwell CS (2002) Excitatory mechanisms in the suprachiasmatic nucleus: the role of AMPA/KA glutamate receptors. J Neurophysiol 88:817-828.

Patneau DK, Wright PW, Winters C, Mayer ML, Gallo V (1994) Glial cells of the oligodendrocyte lineage express both kainate- and AMPApreferring subtypes of glutamate receptor. Neuron 12:357-371.

Paz Soldan MM, Warrington A, Bieber AJ, Ciric B, Van Keulen VK, Pease LR, Rodriguez M (2003) Remyelination-promoting antibodies activate distinct $\mathrm{Ca}^{++}$influx pathways in astrocytes and oligodendrocytes: relationship to the mechanism of myelin repair. Mol Cell Neurosci 22:14-24.

Pende M, Fisher TL, Simpson PB, Rusell JT, Blenis J, Gallo V (1997) Neurotransmitter and growth factor-induced cAMP response element binding protein phosphorylation in glial cell progenitors: role of calcium ions, protein kinase $\mathrm{C}$, and mitogen-activated protein kinase/ribosomal S6 kinase pathway. J Neurosci 17:1291-1301.

Pribyl TM, Campagnoni CW, Kampf K, Kashima T, Handley VW, McMahon J, Campagnoni AT (1993) The human myelin basic protein gene is included within a 179-kilobase transcription unit: expression in the immune and central nervous systems. Proc Natl Acad Sci USA 90:10695-10699.

Pribyl TM, Campagnoni CW, Kampf K, Ellison JA, Landry CF, Kashima T, McMahon J, Campagnoni AT (1996) Expression of the myelin basic protein gene locus in neurons and oligodendrocytes in the human fetal central nervous system. J Comp Neurol 374:342-353.

Reyes SD, Campagnoni AT (2002) Two separate domains in the golli myelin basic proteins are responsible for nuclear targeting and process extension in transfected cells. J Neurosci Res 69:587-596.

Sanchez-Gomez MV, Matute C (1999) AMPA and kainate receptors each mediate excitotoxicity in oligodendrocyte cultures. Neurobiol Dis 6:475-485.

Simpson PB, Armstrong RC (1999) Intracellular signals and cytoskeletal elements involved in oligodendrocyte progenitor migration. Glia 26:22-35.

Simpson PB, Mehotra S, Lange GD, Russell JT (1997) High density distribution of endoplasmic reticulum proteins and mitochondria at specialized $\mathrm{Ca}^{++}$release sites in oligodendrocyte processes. J Biol Chem 272:22654-22661.

Simpson PB, Holtzclaw LA, Langley DB, Russell JT (1998) Characterization of ryanodine receptors in oligodendrocytes, type 2 astrocytes, and $\mathrm{O}-2 \mathrm{~A}$ progenitors. J Neurosci Res 52:468-482.

Soliven B (2001) Calcium signalling in cells of oligodendroglial lineage. Microsc Res Tech 52:672-679.

Stariha RL, Kikuchi S, Siow YL, Pelech SL, Kim M, Kim SU (1997) Role of extracellular signal-regulated protein kinases 1 and 2 in oligodendroglial process extension. J Neurochem 68:945-953.

Suzumura A, Bhat S, Eccleston PA, Lisak RP, Silberberg DH (1984) The 
isolation and long-term culture of oligodendrocytes from newborn mouse brain. Brain Res 324:379-383.

Takeda M, Nelson DJ, Soliven B (1995) Calcium signaling in cultured rat oligodendrocytes. Glia 14:225-236.

Tottene A, Moretti A, Pietrobon D (1996) Functional diversity of P-type and R-type calcium channels in rat cerebellar neurons. J Neurosci 16:6353-6363.

Tzeng SF, Deibler GE, DeVries GH (1995) Exogenous myelin basic protein promotes oligodendrocyte death via increased calcium influx. J Neurosci Res 42:768-774.

Verity AN, Bredesen D, Vonderscher C, Handley VW, Campagnoni AT (1993) Expression of myelin protein genes and other myelin components in an oligodendrocytic cell line conditionally immortalized with a temperature-sensitive retrovirus. J Neurochem 60:577-587.

von Kugelgen I, Wetter A (2000) Molecular pharmacology of P2Y receptors. Naunyn-Schmiedeberg's Arch. Pharmacol 362:310-323.

Yong VW, Sekiguchi S, Kim MW, Kim SU (1988) Phorbol ester enhances morphological differentiation of oligodendrocytes in culture. J Neurosci Res 19:187-194.

Yong VW, Cheung JCB, Uhm JH, Kim SU (1991) Age-dependent decrease of process formation is augmented by protein kinase C stimulation. J Neurosci Res 29:87-99.

Yoo ASJ, Krieger C, Kim S (1999) Process extension and intracellular $\mathrm{Ca}^{++}$ in cultured murine oligodendrocytes. Brain Res 827:19-27. 